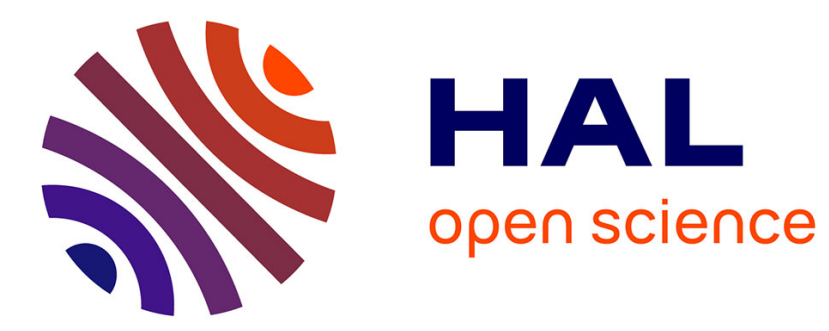

\title{
Firms' sponsored training and productivity in Morocco
}

Khalid Sekkat

\section{To cite this version:}

Khalid Sekkat. Firms' sponsored training and productivity in Morocco. The Journal of Development Studies, 2011, pp.1. 10.1080/00220388.2010.536218 . hal-00721637

\section{HAL Id: hal-00721637 \\ https://hal.science/hal-00721637}

Submitted on 29 Jul 2012

HAL is a multi-disciplinary open access archive for the deposit and dissemination of scientific research documents, whether they are published or not. The documents may come from teaching and research institutions in France or abroad, or from public or private research centers.
L'archive ouverte pluridisciplinaire HAL, est destinée au dépôt et à la diffusion de documents scientifiques de niveau recherche, publiés ou non, émanant des établissements d'enseignement et de recherche français ou étrangers, des laboratoires publics ou privés. 


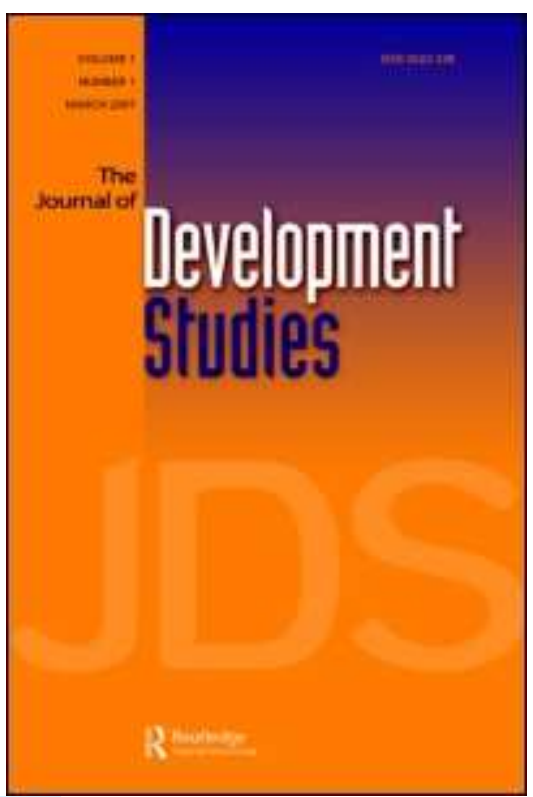

\section{Firms' sponsored training and productivity in Morocco}

\begin{tabular}{|r|l|}
\hline Journal: & Journal of Development Studies \\
\hline Manuscript ID: & FJDS-2009-Aug-0005.R3 \\
\hline Manuscript Type: & Original Manuscripts \\
\hline Keywords: & $\begin{array}{l}\text { Diversification < Economics, Economic development < Economics, } \\
\text { Industrial development < Economics, Globalisation < Social Issues }\end{array}$ \\
\hline \multicolumn{2}{|c}{} \\
\hline
\end{tabular}

\section{SCHOLARONE Manuscripts}




\title{
Firm sponsored training and productivity in Morocco
}

\author{
August 2010 \\ Abstract: \\ Using a sample of around 500 large and small firms covering six industries in Morocco, \\ the paper investigates the relationship between a firm's training decision in 1999 and \\ labour productivity in subsequent years. The analytical framework allows output to \\ depend on unobserved-time-invariant firm characteristics and assumes that technical \\ progress depends on training. Controlling for unobserved heterogeneity among firms \\ and correcting for potential self-selection and endogeneity bias, the estimation shows \\ that the intensity of training has a significant and positive impact on productivity in \\ small and medium enterprises. The finding is robust to the introduction of various \\ control variables.
}

Keywords: Training; Productivity; LDCs JEL classification: J24; D24; O24; O33 


\section{Introduction}

The change in economic strategy initiated in the mid-1980s and accelerated during the 1990s by many developing countries (DCs) aimed at putting their economies on a path of higher efficiency and, hence, fostering growth and development. Trade liberalization constituted a major pillar of the new strategy but puts DCs' firms in the face of intense competition. To survive, they must improve their competitiveness in both domestic and foreign markets. One way of improving firm competitiveness is increasing productivity through worker training.

The paper uses the experience of Morocco to assess the potential of worker training to increase firm productivity in DCs. Morocco is classified by the World Bank as a lower middle income country. The Moroccan average purchasing power parity (PPP) per capita income over the period 2000-2005 was US\$4035, above Sub-Saharan-Africa (SSA) average (US\$2591) but far below some SSA countries (such as US\$11060 in Mauritius and US\$5632 in Gabon) and its Maghreb neighbours (US\$6283 in Algeria and US\$7447 in Tunisia). More importantly, the evidence reported by Johanson and Adams (2004) regarding the challenge of skill availability in SSA suggests that the problem is similar in Morocco. Like many DCs, Morocco is engaged in an ambitious program of economic reform aimed at fostering growth and development through the shift from exports of primary to manufactured products. Compared to African countries, Morocco stands at a high-medium level in terms of the ratio of manufactured exports to GDP (14 per cent on average over 2000-2005). In Botswana, Mauritius and Tunisia the ratio is above 25 per cent while it is below five per cent in Gabon and Kenya and even below one per cent in Algeria. As stated above, to fulfil their ambition of growth 
through manufactured exports, countries should increase firm productivity. Worker skills might be crucial in this respect, although the level of human capital in many of these countries is very low. The school enrolment ratio (average 2000-2005) in Morocco is 44 per cent, far below Algeria, Tunisia, Mauritius and Botswana (above $75 \%$ ) but comparable to Kenya and Gabon (above $40 \%$ ).

A number of African countries sought to address the potential skill shortage through vocational training. Many programs were set up such as "Contrats Spéciaux de Formation" in Morocco (CSF), the Industrial Training Levy Fund in Kenya, the Industrial Vocational Training Board in Mauritius, the National Continuing Training Programme in Tunisia or the Fund to Promote Continuing Vocational Training in Algeria. Whether such programs are able to improve firm productivity and strengthen their competitiveness, is the question we seek to investigate in this paper through the Moroccan experience. Such research is especially important because some evidence suggest that firms are still not taking an active part in training programs. For instance, a survey suggests that only 13 per cent of Moroccan firms have provided training to their employees in 1999 (World Bank, 2000). Another survey, reported by Rosholm et al. (2007), suggests that less than 12 per cent of workers received training in Kenya and Zambia. These figures are to be compared to East Asian countries where training incidence varies from 30 to 50 per cent (World Bank, 2002).

The low involvement of African firms in training might suggest that they do not see any positive impact of training on their performance. This might not be the case in reality and an empirical assessment of the impact of training on productivity proves necessary. If such an impact is found to be positive and significant, one can conclude that training could be an effective way for these countries to improve their competitiveness. The 
finding would also suggest that firms in these countries are missing an opportunity to improve their productivity and competitiveness through worker training.

Firms invest in training if it is beneficial to them through, for instance, higher productivity. A number of empirical studies sought to assess the impact of firm sponsored training on productivity. Focusing mainly on developed countries, their results are divergent (Bartel, 1994; Black and Lynch, 2001; Barrett and O'Connell, 2001; Ballot et al., 2006; Zwick, 2006). While the issue is crucial for DCs too, there are very few published papers on the effects of training in such countries (see below), and none specifically address productivity. Empirical analyses (Lee and Vivarelli, 2005) suggest that the impact of trade liberalization on DCs depends, among other things, on their ability to upgrade their capabilities. Rodrik (1995) showed that the availability of adequate human capital and co-ordination by the government of substantial capital imports have been key factors behind the impressive performances of Korea and Taiwan.

The available papers dealing with the impacts of training in DCs focus on employment, wages and promotion rather than productivity. Revenga et al. (1994) found that in Mexico training reduces the mean duration of unemployment and increases the monthly earnings of men. Attanasio et al. (2008) showed that training raises earnings and employment in Colombia. Aedo and Nuñez (2001), focusing on Argentina, concluded that training positively affects earnings and employment. Muller and Nordman (2004) found that, in two specific industries (that is Textile-clothing and Electrical-Mechanical industries) better education and on-the-job training increase Moroccan workers earnings and employment. Rosholm et al. (2007) focused on the impact of training on workers' earnings in Kenyan and Zambian manufacturing firms and found weak support for a positive return on training. 
While the above evidence pertains to formal training, other research examines the impact of informal training where workers learn informally by watching and imitating colleagues. For instance, Nordman and Wolff (2007) estimated the impact of informal training on workers earnings in Morocco and Senegal. They found that the rates of return to learning-by-oneself are affected by the possibility of learning-by-watching. Yamauchi et al. (2009) examined returns to informal training using employee panel data in Thai manufacturing industries. The findings demonstrated significant positive effect of such training on wages.

Our analysis is conducted at the firm level and focuses on labour productivity. It combines information from two data sets pertaining to Morocco. The first one comes from the Firm Analysis and Competitiveness Survey (FACS) carried out in 2000 by the Ministry of Trade and Industry and the World Bank. The second comes from the yearly survey conducted by the Ministry of Trade and Industry. Both data sets are discussed in detail in Section 3. They are similar to the ones recently used in studies focusing on manufacturing firms in Africa. Using the FACS data set, Fafchamps et al. (2008) examined whether market learning and productivity learning enable firms to export, while Fafchamps (2009) tested whether manufacturing exporters pay more to educated workers. Ramachandran and Shah (1999) used data from the Regional Program on Enterprise Development (RPED) to examine the relationship between minority entrepreneurship and firm performance in SSA, while Van Biesebroeck (2005) used similar data to examine whether exporting raises productivity in SSA manufacturing firms.

It is worth noting that our concern is not the firm's decision to engage in training. Taking such a decision as given, the question concerns the impact on labour productivity. Our objective is to investigate the relationship between a firm's training 
decision in 1999 and labour productivity in subsequent years (2000-2004). The analytical framework is a combination of the model by Greenaway et al. (1999) and the two steps estimation procedure proposed by Black and Lynch (2001) and further developed by Zwick (2006). Assuming a Cobb-Douglas production function for firms, the output is determined by the use of materials, capital and labour. It is also affected by the state of technology, which is not supposed to be exogenous but depends on training. Furthermore, output is allowed to depend on other unobserved-time-invariant firm characteristics.

The rest of the paper is organised as follows. Section 2 briefly describes the Moroccan context. Section 3 presents the data to be used. Section 4 discusses the econometric approach. Section 5 analyses the results and Section 6 concludes.

\section{The Moroccan context}

Morocco started liberalizing foreign trade in 1983 and strengthened the process in the 1990s. As explicitly asserted in the Foreign Trade Law of 1992, trade liberalization was intended to promote exports and integrate the Moroccan economy into the world economy. By implementing the foreign trade law, Morocco committed itself to liberalize imports and exports of goods and services, abolish any quantitative restrictions, and use exclusively tariffs in protecting domestic production.

Morocco joined the GATT in 1987. It has also signed a Free Trade Agreement (FTA) with the European Union (EU) in 1995, which started being effectively implemented in 2000. In addition to the FTA with EU, Morocco has other bilateral and regional trade agreements such as the free-trade agreement with EFTA (1997), the Arab FTA (1998). More recently, Morocco signed FTAs with the United States (2004) and Turkey (2004). 
Table 1. School enrolment ratios 2002-2003.

Morocco shares an important characteristic with a number of DCs, namely a low level of human capital and the emphasis put on training to fill this gap and improve the economy's competitiveness. Table 1 shows that the school enrolment ratio in 2002/2003 (All levels except pre-primary) was the lowest in Morocco as compared to similar countries in the Middle East and North-African, but it was higher (although not by much) than the African average.

(All levels except pre-primary)

\begin{tabular}{|c|c|c|c|}
\hline Country & Ratio & Region & Ratio \\
\hline Algeria & 74 & Africa & 52 \\
\hline Egypt & 74 & North America & 84 \\
\hline Jordan & 78 & South America & 86 \\
\hline Lebanon & 79 & Asia & 64 \\
\hline Morocco & 58 & Europe & 91 \\
\hline Syria & 62 & & \\
\hline Tunisia & 74 & & \\
\hline Turkey & 68 & & \\
\hline
\end{tabular}

Source: UNESCO: http://www.uis.unesco.org/.

This low level of human capital may result in skill shortages and negatively affects the capacity of Moroccan firms to effectively compete with foreign firms. In Morocco, like in many African countries, governments try to address this problem by setting programs to train workers (for example CSF in Morocco).

The system of the "Contrats Spéciaux de Formations" (CSF) revived in 1996 was set up in 1974 at the same time as the "Office de la Formation Professionnelle et de la Promotion du Travail" (OFPPT). The CSF objective is to encourage firms to incorporate training into their development plans. They are contracts between the government, the firms and the workers that involve refunding to firms the expenses incurred in organizing training programs for employees. The CSF provide financial assistance for both the drafting and the implementation of training plans. They are 
managed on a tripartite basis (government, employers and employees) and in a decentralized way. In addition to a central tripartite committee at the national level, there are ten tripartite regional committees covering the entire country. The training can be provided by either public or private bodies. A recent study (ETF, 2008) evaluating the CSF concluded that they improved the performance of the companies having used them. However, their effects differ depending on whether the company sees CSF mainly as a means to reduce its training costs or as a component of its overall modernisation and development strategy.

\section{The data}

\subsection{The original data}

To perform our analysis, we combine two data sets. One set comes from the Moroccan Census of Manufacturing conducted by the Moroccan government, while the second is the Firm Analysis and Competitiveness Survey (FACS, 2000) ${ }^{1}$ conducted in 2000 by the World Bank and the Moroccan government on selected firms. The sets allocate the same code to the same firm. If this firm quits the market, the code is not allocated to another firm. New firms receive new codes. This allows matching of the two data sets and following the same firms over time.

The Annual Moroccan Census of Manufacturing surveys all manufacturing firms with at least 10 employees or with sales revenue exceeding 100,000 Moroccan Dirham (MAD). ${ }^{2}$ The firm's activity is described by the four-digit Moroccan nomenclature of economic activities (Nomenclature Marocaine des Activités Economiques; NMAE). The survey gives information about firm's sales revenue, output, exports, investment, labour cost and number of employees (without skill decomposition). 
The FACS provides data for more than 800 firms covering mainly Textiles, Garments, Processed Food Products, Chemicals, Leather and Shoes products and Plastic products. These industries, drawn from a classification that includes 26 industries, represent together around 80 per cent of the whole manufacturing sector employment and exports and more than 50 per cent of its value added. Like the Census, FACS concerns manufacturing firms with at least 10 employees. Its instrument was a written questionnaire filled by direct interviews with the management and staff of the firm. The questions refer to the situation in 1999 and concern the origin and shareholding status of the firm (foreign vs. domestic), background of the owner or manager, technology, labour market, contractual relations, financial markets, international trade etc. More importantly, the FACS gives the value of the physical capital stock for each firm in 1999 and the responses to the following questions:

- During the year 1999, did you offer training programs?

- If yes, what was the number of participants and the average duration (number of days)?

- If yes, how much did it cost in MAD?

The questions are about formal training offered by the firm either on-site or in external institutions. They do not concern apprenticeships. The answers to the above questions allow us to construct three explanatory variables. One is just a dummy reflecting whether a firm offered training in 1999. The second reflects the intensity of training: the average number of days of training per worker. The third relates to the cost of training: the total cost of training divided by the total number of workers. 


\subsection{The data used in the estimation}

After dropping missing values and combining the two data sets, we end up with around 500 firms to investigate the impact of training on productivity. Table 2 summarizes the main characteristics of the resulting sample. It shows that firms operating in textiles and garment together represent 60 per cent of the number of firms, which reflect the importance of the two industries in Moroccan manufacturing. The share of firms aged between 11 and 20 years is the highest and the share of firms having between 20 and 49 workers is the highest. Large firms (that is with at least 200 workers) represent a nonnegligible share of the total.

Around 14 per cent of firms provide training. Firms that offer training devote an average of around two days and 16 MAD per worker. The standard deviations, around three days and 74 MAD, suggests that there are non-negligible differences between firms. These figures are comparable to those reported by Barrett and O'Connell (2001) for Ireland. In terms of category of workers receiving training, skilled blue collar receive the largest share of the total number of person- days of training (54\%). Directors and white collar (managers, engineers) receive around 23 per cent of the total number of person- days of training. 
Table 2. Characteristics of the sample used in the regressions (FACS matched with the Census of Manufacturing)

Firms per activity in 1999 (per cent of number of firms )

Food

Textile

22.33

Clothing

37.60

Leather and footwear $\quad 11.66$

$\begin{array}{lr}\text { Chemicals } & 7.23\end{array}$

$\begin{array}{lr}\text { Plastic } & 11.33\end{array}$

Descriptive statistics of output per firm per year (MAD 1000)

$\begin{array}{lrr} & \text { Mean } & \text { Median } \\ \text { Food } & 64253 & 30268 \\ \text { Textile } & 24434 & 8195 \\ \text { Clothing } & 19066 & 6602 \\ \text { Leather and footwear } & 11687 & 4818 \\ \text { Chemicals } & 59449 & 18026 \\ \text { Plastic } & 18654 & 6634\end{array}$

Firms per age (number of years) in 1999 (per cent of number of firms )

$0-5$

6-10

20.36

$11-20$

35.47

21-30

16.58

$31-40$

7.39

Above 40

Firms per size (number of employees) in 1999 (per cent of number of firms )

$0-9$

100-199

18.63

Above or equal to 200

18.02

Share of firms offering training (per cent of number of firms )

Number of days of training per employee in firms offering training

Average

Standard deviation

Cost per employee in firms offering training (MAD)

Average

Standard deviation

Share by categories of workers in the total number of day-person of training (per cent)*

Total 


\section{Econometric analysis}

\subsection{The model}

We follow Greenaway et al. (1999) Black and Lynch (2001) in assuming that the technology of firm $i$ is described by an augmented Cobb-Douglas production function with constant return to scale:

$$
Q_{i}=A_{i} K_{i}^{\delta} L_{i}^{\alpha} M_{i}^{\beta}
$$

Where $Q$ is output, $A$ is an index of technological progress, $L$ is labour, $K$ is capital stock, $M$ is material and $\alpha=1-\delta-\beta$. Taking logs and expressing equation (1) in terms of production per worker gives:

$$
\begin{aligned}
& \log \left(Q_{i} / L_{i}\right)=\log \left(A_{i}\right)+\delta * \log \left(K_{i} / L_{i}\right)+\beta * \log \left(M_{i} / L_{i}\right) \\
& \text { or } \\
& q_{i}=a_{i}+\delta * k_{i}+\beta * m_{i}
\end{aligned}
$$

Traditionally, $A_{i}$ is supposed to be exogenous. Here, in contrast, we assume that $A_{i}$ is endogenous and depends on firm practices $Z_{i}$ concerning training, which gives:

$$
A_{i}=e^{\eta^{*} Z i}
$$

Taking equations (2) and (3) together and incorporating a firm's idiosyncratic error term, $\xi_{i t}$, implies that the production per employee of firm $i$ at time $t$ equals: 
$q_{i t}=\eta^{*} Z_{i}+\delta * k_{i t}+\beta * m_{i t}+\xi_{i t}$

Equation (4) serves as a basis for most of the empirical analysis in this field. However, as noted in the introduction, there are marked differences in the results across studies. Following Zwick (2006), one major reason for the differences is the estimation approaches. We deal with this problem in the next sub-section.

\subsection{Estimation issues}

\section{Firm heterogeneity}

Bartel (1994) estimated a simple cross-section production function including a dummy for formal training programs and found no effect of training on productivity. This may be due to unobserved heterogeneity between firms, which leads to a correlation between the formal training measure and the error term (Griliches and Mairesse, 1997). In order to avoid this bias Barrett and O'Connell (2001) regress the change in productivity (instead of its level) on the level of training intensity. The effect of training on changes in productivity was positive and significant. However, taking the productivity equation in first difference may be problematic. If training is (like the unobserved heterogeneity) time-invariant, its effect should vanish when taking differences and one cannot assess its impact on productivity. If training is time-variant like investment, differencing does not remove its effect which raises other issues discussed below.

When training is time-invariant, Black and Lynch (2001) used a two steps method to deal with unobserved heterogeneity. In the first step, they calculated the average firm specific time-invariant residual using a fixed effects Cobb-Douglas production function without training (which is time-invariant in their sample). In the second step, they 
regressed the average establishment residual on training and the other quasi-fixed factors. Formally, the procedure is the following:

First step: conduct a within estimation of equation (4) in first difference:

$\Delta q_{i t}=\delta * \Delta k_{i t}+\beta * \Delta m_{i t}+\Delta \xi_{i t}$

take the estimates of $\delta$ and $\beta$ to generate the predicted values:

$q_{i t}-\delta * k_{i t}-\beta * m_{i t}=\eta^{*} Z_{i}+\Delta \xi_{i t}$,

and average these values over the period of observation for each firm to get an estimate of the firm-specific time-invariant component of the residual.

Second step: regress the averages on the various indicators of training.

Note that when training is time-variant, this two step method may under or over estimate the effect on productivity. Training in any relevant years, other than the one for which we have data, enters the error term in equation (5). If capital investment, $k$, is positively (negatively) correlated with training, the estimated residual in equation (6) will be under (over) estimated and so to is the effect of training on productivity. ${ }^{3}$ As the data do not permit addressing this issue (training is only known in one year), we assume that training is time-invariant in the analysis.

\section{Selection bias}

As Black and Lynch (2001) admitted, the above procedure only addresses the unobserved heterogeneity among firms but is still prone to selectivity bias. Actually, 
while firms may become more productive because of training, it could also be the case that the more productive firms self-select into training. ${ }^{4}$ To deal with the potential selfselection bias (that is the more productive firms are those that offer training), we control for the productivity of firms prior to training by introducing the productivity in 1999 as an explanatory variable in the second step.

\section{Endogeneity of factors of production}

Production and inputs are, in general, chosen simultaneously. Hence, the within estimator of equation (5) might be inconsistent. To address this issue, one can use either 2SLS or GMM estimation methods for equation (5). A major problem with the use of these methods concerns the choice of the instruments. The instruments should be highly correlated with the variables to be instrumented to be strong in Murray (2006) terminology. They should also be uncorrelated with the disturbances of the equation of interest (in our case equation 5); that is the instruments should be valid in Murray (2006) terminology. Sometimes, economic theory helps identify strong and valid instruments. In general, however, economic interactions might be so complex and numerous that economic theory alone is not helpful to identify strong and valid instruments. Moreover, one can imagine a scenario where the chosen instruments are strong and valid but it is often possible to find another scenario where the instruments are not (Durlauf et al., 2005). Therefore, econometric tests become the best solution to judge whether the chosen instruments are strong and valid. Murray (2006) suggests using the Staiger and Stock (1997) "rule" to examine whether instruments are strong and the Sargan (1958) test to judge their validity. Following Staiger and Stock, the instruments can be considered as good if the first-stage F-statistic of the regression of the variable to be instrumented on the instrument is above 10. The Sargan test regresses 
the residuals from the IV estimation of the equation of interest on the instruments and uses the $\mathrm{R}^{2}$ to test the significance of this regression. The test statistic is the number of observations times the $\mathrm{R}^{2}$ and has a chi-square distribution. Its degree of freedom is equal to the number of instrument minus the number of variable to be instrumented. This is the approach adopted here and relevant statistics are reported in Table 3.

\subsection{Measurement issues}

There are four measurement issues to consider: intermediate input, firms' practices, capital stock and deflators.

\section{Intermediate input}

In our data sets, information on intermediate input (material) is not available. Assuming that firm intermediate input per employee is equal to industry average $m_{t}$ plus an error term (that is $m_{i t}=m_{t}+\varepsilon_{i t}$ ) which is uncorrelated with $m_{t}$ and $k_{i t}(\log$ of capital stock), we introduce year-industry dummies to control for intermediate input in equation (5).

\section{Firm' practices}

In equation (4), training (that is firm practice $Z_{i}$ ) is assumed time invariant. In reality, this is not necessarily true. In our framework, such constraint is imposed by data availability. The dataset used here gives information on training only for one year (that is 1999). Hence, the changes in training intensity across years are contained in the error terms. This may induce under or over estimation of the effect of training on productivity and should be kept in mind when analyzing the results. Hence, our conclusion depends on the assumption that firm practices are reasonably constant over time. Constraining our estimation to years close to 2000 , we expect the effects on our estimates (due to 
change in training across years) to be limited. A similar approach is adopted in Black and Lynch (2001).

\section{Capital stock}

We do not have a measure of firm's capital stock for every year. We use the standard perpetual inventory method to construct an estimate of the value of the capital stock. Given $K_{i 1999}$ the capital stock of firm $i$ in 1999 provided by FACS, $I_{i t}$ investment of firm $i$ in year $t$ (provided by the Census for 2000-2004) and $\theta$ the economic rate of depreciation of capital, then $K_{i 1999+t}=K_{i 1999} *(1-\theta)^{t}+($ sum of weighted investment between 1999 and $1999+t$ ). We consider three different values for $\theta$ (that is $5 \%, 7 \%$, and $10 \%$ ). The main results are not sensitive to changes in $\theta$ (see below in Section 5).

\section{Deflators}

The raw data of production and investment are available in current prices only. To get them in constant prices we use the output and the investment deflators, which are only available for the whole manufacturing sector.

\section{The results}

The empirical analysis investigates the impact of training offered to workers in 1999 on their average productivity over the period 2000-2004. As stated in the introduction, the results of similar studies focusing on developed countries are divergent. While the difference in the results across studies covering different countries are easily understandable (due to labour market institutions for instance), differences concerning the same country and the same period are striking. A close look at the literature suggests that, in addition to the estimation approaches discussed above, such differences might 
be related to the indicators of training (dummy vs. intensity), the firm size (large vs. small), sector composition of the sample (manufacturing vs. non manufacturing) and the measure of the dependent variable (level vs. growth of productivity).

The sample we are using in the present study allows us to address these issues. The existence of training and its intensity can be distinguished, a fairly balanced distribution of firm size is available and the time dimension of production, labour and capital data can be exploited to examine the impact of training on productivity growth. The use of the two-step estimation approach addresses unobserved firm heterogeneity. Finally, to deal with the potential self-selection bias (that is the more productive firms are those that offer training), we control for the productivity of firms prior to training by introducing the productivity in 1999 as an explanatory variable in the second step.

The estimation results of equation (5), the first step, are reported in Table $3 .^{5}$ Two estimation approaches were adopted. In the first approach the two stage least squares (2SLS) estimation where the change in capital is regressed on investment in $t$ - 2 and in $t$ 3 and the fitted values of such change are incorporated in equation (5). To control for intermediate input, the estimation includes year-industry dummies (as explained above). Estimation of equation (5) includes interaction terms (that is change in capital time industry dummy) to allow different coefficients of capital by industry. In the second approach the GMM estimation is implemented in the traditional way; for instance, lagged values of the explanatory variable (the change in capital in $t-2$ and in $t-3$ ) are used as instruments. Firm and year-industry dummies as well as interaction terms are included for the same reason as before.

Table 3 reports the results of both estimation methods for different values of $\theta(5 \%, 7 \%$ and $10 \%$ ). The last two lines in the table allow judging the quality of the instruments used in the first stage of the 2SLS and in the GMM. The F-statistics are all well above 
10; which shows that the instruments are strong (Staiger and Stock, 1997). In other words, the instruments are highly correlated with the instrumented variable. The Sargan statistics, distributed as $\chi^{2}(1)$ in our case, are significant at the 10 per cent (but not at the 5\% level) when the 2SLS method is used. When the GMM is used, the statistics are non-significant. This means that the instruments are only valid when GMM is used, as they are not correlated with the disturbances in equation (5). Hence, as shown by Murray (2006), our GMM estimates are reliable.

The estimated coefficients of capital per industry reported in Table 3 are not sensitive to the value of the economic rate of depreciation of capital $(\theta)$. With each estimation method, they remain broadly the same when $\theta$ changes. Hence, given the above discussion about the reliability of the estimates, we will use the GMM results pertaining to $\theta=7$ per cent in what follows. 
Table 3: Coefficient of capital by industry

\begin{tabular}{|c|c|c|c|c|c|c|}
\hline & \multicolumn{3}{|c|}{ 2SLS } & \multicolumn{3}{|c|}{ GMM } \\
\hline & $\theta=0.05$ & $\theta=0.07$ & $\theta=0.10$ & $\theta=0.05$ & $\theta=0.07$ & $\theta=0.10$ \\
\hline Food & 0.81 & 0.81 & 0.80 & 0.70 & 0.69 & 0.69 \\
\hline Textiles & 0.40 & 0.40 & 0.39 & 0.51 & 0.50 & 0.49 \\
\hline Garment & 0.51 & 0.51 & 0.50 & 0.62 & 0.61 & 0.60 \\
\hline Leather & 0.58 & 0.57 & 0.57 & 0.28 & 0.28 & 0.27 \\
\hline Chemical & 0.47 & 0.46 & 0.46 & 0.53 & 0.52 & 0.52 \\
\hline Plastic & 0.57 & 0.57 & 0.57 & 0.74 & 0.73 & 0.72 \\
\hline Number of observations & 2158 & 2158 & 2158 & 2158 & 2158 & 2158 \\
\hline Adjusted $\mathrm{R}^{2}$ & 0.08 & 0.08 & 0.08 & 0.26 & 0.26 & 0.26 \\
\hline F-statistic: Strong instruments? & $32.11^{\mathrm{a}}$ & $32.55^{\mathrm{a}}$ & $33.24^{\mathrm{a}}$ & $24.32^{\mathrm{a}}$ & $25.01^{\mathrm{a}}$ & $26.13^{\mathrm{a}}$ \\
\hline Sargan test: Valid instruments? & 3.56 & 3.53 & 3.47 & 2.50 & 2.42 & 2.29 \\
\hline $\begin{array}{l}\text { F-statistic: significance of } \\
\text { year-industry dummies }\end{array}$ & 211.51 & 211.87 & 212.11 & 211.20 & 211.43 & 211.76 \\
\hline
\end{tabular}

Notes: Standard Errors are heteroskedastic-consistent, all coefficients (t-statistics not reported) are significant at the $1 \%$ level; Sargan statistic significant at $10 \%$ and F-statistic significant at $1 \%,{ }^{a}=$ Above the value recommended by Staiger and Stock (1997).

The estimation results using equation (6), the second step, are presented in Table 4. We added to the regression industry dummies (their coefficients are not reported) and the productivity level in 1999 (to control for self-selection). We have six sets of results: with a dummy, intensity or cost of training and with or without the productivity level in 1999. When the productivity level in 1999 is included, the quality of fit improves markedly (the adjusted $\mathrm{R}^{2}$ jumps from 0.39 to 0.77 ) and is higher than in recent studies using the same methodology (Zwick, 2006). The coefficients of the lagged productivity are highly significant. Interestingly, the coefficients of training remain or become significant and positive irrespective of the indicator (dummy, intensity or cost). Their magnitude change only slightly with the introduction of the 1999 productivity level. 
Controlling for potential self-selection, the impact of training on productivity is consistently positive and significant.

The coefficient of the intensity of training (3\%) is higher than in Barrett and O'Connell (2001) for Ireland (1.4\%). It implies that a firm offering one more day of training for all workers should have three per cent higher productivity than a firm that does not. Similarly, two firms with one standard deviation difference in training efforts will have a nine per cent difference in productivity. Ballot et al. (2006), using the expenditure per employee as a measure of the cost of training, found a coefficient of 23 per cent in France and 1.1 per cent in Sweden. ${ }^{5}$ With a similar measure, we obtain a coefficient of two per cent. Hence, in Morocco training seems to have a higher positive impact on productivity than in Sweden. 
Table 4: Impact of training on productivity

\begin{tabular}{|c|c|c|c|c|c|c|}
\hline \multirow[b]{3}{*}{ Constant } & \multicolumn{6}{|c|}{ Specification } \\
\hline & 4.1 & 4.2 & 4.3 & 4.4 & 4.5 & 4.6 \\
\hline & $1.48 \quad(14.13)$ & $1.49(14.32)$ & 1.49 (11.91) & $0.23 \quad(2.59)$ & $0.24 \quad(2.69)$ & $0.23 \quad(2.17)$ \\
\hline Dummy & $0.18 \quad(2.28)$ & & & $0.14(2.81)$ & & \\
\hline Number of days & & $0.05 \quad(2.63)$ & & & $0.03 \quad(2.43)$ & \\
\hline Cost & & & $0.03(0.75)$ & & & $0.02(2.09)$ \\
\hline Productivity in 1999 & & & & $0.75(20.56)$ & $0.75(20.50)$ & 0.78 (18.76) \\
\hline Number of observations & 488 & 488 & 352 & 488 & 488 & 352 \\
\hline Adjusted $\mathrm{R}^{2}$ & 0.39 & 0.39 & 0.39 & 0.77 & 0.77 & 0.77 \\
\hline F-stat. (overall significance) & 45.19 & 45.24 & 33.28 & 200.60 & 199.20 & 146.43 \\
\hline
\end{tabular}

Notes: Standard Errors are heteroskedastic-consistent, t-statistics are in parentheses.

To check the robustness of our findings, we consider other potentially relevant explanatory variables. First, we introduce the age of the firm. Young businesses may have low levels of productivity because of the necessity to learn about technology and management. Bartel and Lichtenberg (1987) provided further discussion on the relationship between labour productivity and the age of plants. Second, export orientation of the firm is included. Bernard et al. (2003) observed higher productivity among exporters and pointed to the role of early foray in making exporting plants have high productivity and large size. This is similar to the notion of "learning from exporting" by Tybout et al. (1998). Third, the share of firm machines that are less than 10 years old is added to the regression. The variable corresponding to this aspect is based on responses to the question: "During the year 1999 what was the share of equipment and machinery aged less than 10 years in your company?". New machinery may increase productivity because of their own function but also because they may be necessary to put new inventions into practice or their introduction may lead to better organization, management and more efficient combination of inputs (DeLong and Summers, 1991). Empirical support to this idea is provided by Coe et al. (1997). 
Finally, our estimated impact of training may depend on the initial human capital of workers. Following Rosholm et al. (2007), those receiving training are, in general, the better-educated workers. Hence, training measured by the number of days of training per person may be correlated with the share of skilled workers in total employees. As skilled workers are likely to have higher productivity than unskilled, our estimates of the impact of training may only reflect the importance of skilled workers in total employees. To see whether training has an impact on its own, we introduce an additional control variable: the share of skilled workers (white-collar workers and skilled blue collar) in total employment in 1999. As we examine the impact of training on productivity between 2000 and 2004, this variable can be considered as predetermined.

Tables 5 and 6 present the results of the robustness check. Since missing values decrease markedly the sample size when the cost of training is considered, we will focus on the two other indicators of training. In Table 5, we use the dummy of training as explanatory variable while in Table 6 we use the intensity of training. There are five sets of results in each table. Four sets where the specification from Table 4 is augmented with each of the control variables separately and a fifth set where all the additional control variables are included. Irrespective of the table under consideration, none of the additional control variables is significant at 5 per cent, the adjusted $\mathrm{R}^{2}$ is unchanged, and both the significance and the level of the coefficients of the indicator of training are unaffected. 
Table 5: Robustness check with a dummy for training

\section{Constant}

Productivity in 1999

Dummy for training

Age of the firm

Share of exports in sales

Share of new machinery (less than 10 years)

Share of skilled workers in 1999

Number of observations

Adjusted $\mathrm{R}^{2}$

F-stat. (overall significance)
Specification

\begin{tabular}{rlllllllll}
\multicolumn{1}{c}{5.1} & \multicolumn{2}{c}{5.2} & \multicolumn{2}{c}{5.3} & \multicolumn{2}{c}{5.4} & \multicolumn{2}{c}{5.5} \\
\hline & & & & & & & & & \\
0.27 & $(2.79)$ & 0.23 & -2.52 & 0.18 & $(1.79)$ & 0.21 & $(2.17)$ & 0.19 & $(1.52)$ \\
0.76 & $(20.58)$ & 0.76 & $(20.49)$ & 0.75 & $(20.48)$ & 0.75 & $(20.57)$ & 0.76 & $(20.48)$ \\
0.16 & $(3.06)$ & 0.15 & $(2.85)$ & 0.15 & $(2.82)$ & 0.14 & $(2.74)$ & 0.15 & $(2.89)$ \\
-.000 & $(1.59)$ & & & & & & & -0.00 & $(0.90)$ \\
& & 0.07 & $(1.60)$ & & & & & 0.06 & $(1.17)$ \\
& & & & 0.09 & $(1.57)$ & & & 0.06 & $(0.95)$
\end{tabular}

Notes: Standard Errors are heteroskedastic-consistent, t-statistics are in parentheses. 
Constant

Productivity in 1999

Average number of training days

Age of the firm

Share of exports in sales

Share of new machinery(less than 10 years)

Share of skilled workers in 1999

Number of observations

Adjusted R ${ }^{2}$

0.77

175.7

F-stat. (overall significance)

\begin{tabular}{|c|c|c|c|c|}
\hline 6.1 & 6.2 & 6.3 & 6.4 & 6.5 \\
\hline $\begin{array}{ll}0.27(2.78) \\
\end{array}$ & $0.24(2.61)$ & $\begin{array}{ll}0.19 & (1.89)\end{array}$ & $0.22 \quad(2.24)$ & $0.18 \quad(1.45)$ \\
\hline 0.76 (20.49) & 0.76 (20.44) & 0.75 (20.43) & $0.75 \quad(20.51)$ & $0.76 \quad(20.39)$ \\
\hline $0.03 \quad(2.49)$ & $0.03 \quad(2.60)$ & $0.03 \quad(2.37)$ & $0.03 \quad(2.42)$ & $0.03 \quad(2.50)$ \\
\hline$-0.00 \quad(1.46)$ & & & & $-0.00 \quad(0.52)$ \\
\hline & 0.07 & & & $0.06(1.30)$ \\
\hline & & 0.09 (1.53) & & 0.06 \\
\hline & & & 0.09 (1.24) & $0.08 \quad(1.10)$ \\
\hline 483 & 488 & 487 & 488 & 482 \\
\hline 0.77 & 0.77 & 0.77 & 0.77 & 0.77 \\
\hline 175.7 & 177.8 & 177.5 & 177.4 & 132.1 \\
\hline
\end{tabular}

Notes: Standard Errors are heteroskedastic-consistent, t-statistics are in parentheses. 
An additional issue we raised when discussing the literature is the size of the firm. Most of the papers we examined used samples of large firms. The impact of training on productivity may, however, differ according to firm size. This may be due, for instance, to economies of scale in training or human resource management. Using panel data on 173 Dutch firms, de Kok (2002) tested for the effect of firm size on the relationship between training and productivity. The author found that small firms benefit less than large ones from the training they provide. To examine the size effect, Rosholm et al. (2007), focusing on Kenya and Zambia, just dropped from their sample the firms with less than 10 employees. Their results are inconclusive.

In order to investigate the effect of firm size on the relationship between training and productivity, we rerun similar regression as in Table 4 on five sub-samples. The subsamples are of relatively comparable dimensions (that is between 100 and 150 observations each). To save on space, Table 7 reports only the coefficients and the $\mathrm{t}$ statistics of training variables. The coefficients of the intensity of training are significant and positive in three instances out of five. The coefficient becomes insignificant for firms with 100 workers or more. 
Table 7: Impact of training on productivity and firm size

\begin{tabular}{|c|c|c|c|c|c|}
\hline Number of workers & $0-19$ & $20-49$ & $\overline{50-99}$ & $100-199$ & Above 199 \\
\hline Number of firms & 103 & 153 & 119 & 112 & 106 \\
\hline Share in total ( per cent) & 17.37 & 25.80 & 20.07 & 18.89 & 17.88 \\
\hline Dummy & $0.91(1.40)$ & $0.22(0.87$ & $0.09(0.95)$ & $0.06(0.91)$ & $0.13(1.14)$ \\
\hline Number of training days per worker & $0.06(6.66)$ & $0.04(2.56)$ & $0.03(2.68)$ & $-0.05(0.27)$ & $0.00(0.09)$ \\
\hline
\end{tabular}

Notes: Standard Errors are heteroskedastic-consistent, t-statistics are in parentheses.

Trying to understand the reason behind the above results, we first re-estimate the same specification over the whole sample adding an interaction term between the intensity of training and each of the additional variables used in Table 6. The results, not reported here, do not lead to any interesting findings. Then, we rerun the specification on two sub-samples; one includes firms with less than 100 workers and the other includes firms with at least 100 workers. This threshold is the one after which the coefficient of training becomes non-significant in Table 7 . We added to each specification one of the additional variables used in Table 6 . The results, reported in Table 8 , show that the coefficient of training remains consistently positive and significant when the sample consisting of firms with less than 100 workers is considered. Furthermore, none of the additional explanatory variables is significant. The results pertaining to the sample consisting of firms with at least 100 workers show that the coefficient of training remains consistently non-significant. However, one of the additional explanatory variables, namely the share of new machinery, becomes positive and significant.

It seems that productivity improvement is driven by different factors depending on the size of the firm. In large firms, improvement of productivity is mainly achieved through new capital investment, while in small firms improvement of productivity is mainly achieved through worker training. This contrast may be due to credit constraint that, in 
general, small firms face and which prevent them from acquiring sophisticated new machinery. Worker training, especially if subsidised by the government, gives small firms an alternative and may be a cheaper way of improving their productivity. Given the importance of such firms in developing countries, the results suggest that workers training could be an effective way of improving a country's competitiveness. 
Table 8: Drivers of firms' productivity following their size

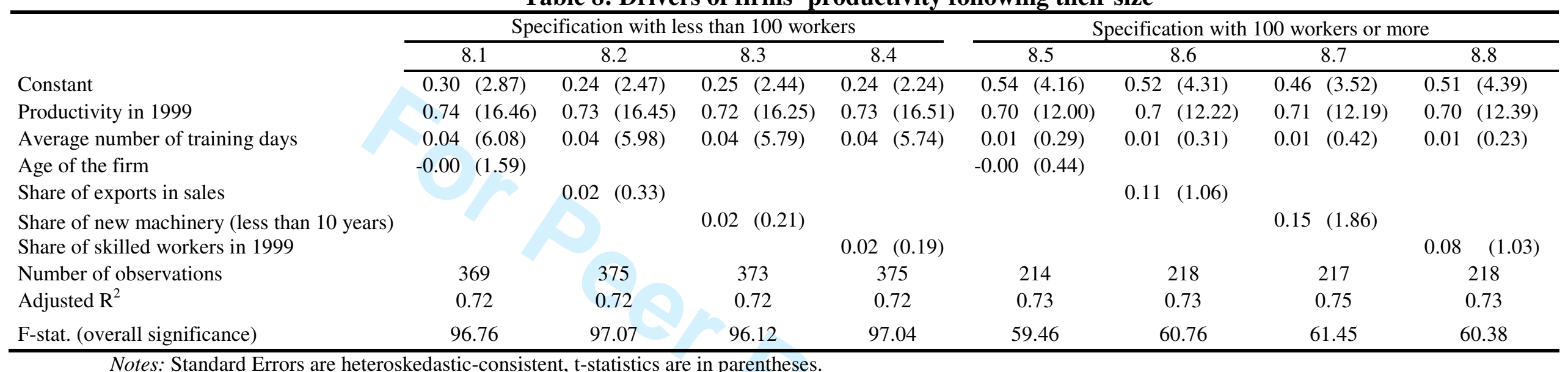

Notes: Standard Errors are heteroskedastic-consistent, t-statistics are in parentheses. 


\section{Conclusion}

Increasing productivity is one way for a firm to improve its competitiveness on national and international markets. Such increase may be achieved by different means, among which worker training has attracted much attention in recent years. Training is especially important for developing countries which face the double challenges of opening up to international competition and the inadequacy between supplied and demanded skills. This paper investigates the extent to which the provision of training to workers by firms helps them increasing their productivity.

The analysis combines two data sets from Morocco to investigate the relationship between a firm's training decision in 1999 and its productivity in subsequent years. The analytical framework assumes a Cobb-Douglas production function for firms where technical progress is not exogenous but depends on training. It also allows output to depend on unobserved-time-invariant firm characteristics and correct for potential endogeneity and self-selection bias.

The estimation results show that training has a significant and positive impact on firm productivity (albeit subject to the assumption that capital stock and training are not correlated for the sample). Two firms with one standard deviation difference in training efforts (that is three days per employee) will have a nine per cent difference in productivity. The magnitude of this effect is higher than in comparable studies for other countries. The finding is robust to the introduction of various control variables.

The impact of training is, however, different according to firm size. The results show that training has a consistently positive and significant impact on the productivity of firms with less than 100 workers. In firms with more than 100 workers, the results show that training has a non-significant impact. Investing in human capital (through workers training) is, therefore, a potential important tool for small and medium enterprises 
1

2

3

4

5

6

7

8

9

10

11

12

13

14

15

16

17

18

19

20

21

22

23

24

25

26

27

28

29

30

31

32

33

34

35

36

37

38

39

40

41

42

43

44

45

46

47

48

49

50

51

52

53

54

55

56

57

58

59

60

(SMEs) to meet the challenge of globalization. Given the importance of such firms in developing countries, the results support government efforts to foster workers training but also imply that such efforts should target SMEs in particular. Moreover, the fact that investment in human capital is subject to market failures, which might hurt SMEs more than large firms, further justifies government support. 
${ }^{1}$ At present, only the results of the FACS 2000 survey are available. It seems that a similar survey is being conducted for other years but the results are not ready.

${ }^{2}$ Between US \$ 9,000 and 12,000.

${ }^{3} \mathrm{We}$ are grateful to a referee for pointing out this problem. In effect, we assume that $k$ and training are not correlated. To the extent that this or the time-invariance assumption is incorrect the estimates will be biased, although we have no basis on which to judge the direction of any bias.

${ }^{4}$ Studies adopt different approaches to address this problem according to the type of data available. For instance, Ballot et al. (2006) and Dearden et al. (2006) used a System Generalized Method of Moments (GMM) with productivity in level and in first differences. Zwick (2006) exploited the personnel department's responses about skill shortages to construct an instrument for the training decision.

5 To save on space, the coefficients of the dummies are not reported. Details are available on request.

${ }^{6}$ The authors gave no explanation for the striking difference between the two countries 


\section{References}

Aedo C. and Nuñez S. (2001) The Impact of Training Policies in Latin America and the Caribbean: The Case of "Programa Joven". Working paper, R-483, Washington, DC: Inter-American Development Bank.

Attanasio, O., Kugler A. and Meghir C. (2008) Training Disadvantaged Youth in Latin America: Evidence from a Randomized Trial. Cambridge, MA: NBER Working Paper, No. 13931.

Ballot G., Fakhfakh F. and Taymaz E. (2006) Who Benefits from Training and R\&D, the Firm or the Workers?. British Journal of Industrial Relations, 44 (3), pp. 473-495.

Barrett. A. and O’Connell P. J. (2001) Does training generally work? The returns to in company training. Industrial and Labor Relations Review, 54 (3), pp. 647-662.

Bartel, A.P. (1994) Productivity gains from the implementation of employee training programs. Industrial Relations, 33 (4), pp. 411-425.

Bartel, A. P. and Liehtenberg F. R. (1987) The Skill Distribution and Competitive Trade Advantage of High-Technology Industries, in: D. Lewin, D. Lipsky, and D. Sockell (eds) Advances in industrial and Labor Relations: Volume 4, (Greenwich, CT: JAI Press), pp. 161-76. 
Bernard A. B., Eaton J., Jensen J. B. and Kortum S. (2003) Plants and Productivity in International Trade. American Economic Review, 93 (4), pp. 1268-1290.

Black S. and Lynch L. (2001) How to Compete: The Impact of Workplace Practices and Information Technology on Productivity. The Review of Economics and Statistics, 83 (3), pp. 434-45.

Coe, D. T., Helpman E. and Hoffmaister A. W. (1997) North - South R\&D spillovers. Economic Journal, 107 (440), pp. 134 - 149.

de Kok, J. (2002) The Impact of Firm-Provided Training on Production Testing for Firm-Size Effects. International Small Business Journal, 20 (3), pp. 271-295.

De Long, J.B. and Summers L. H. (1991) Equipment Investment and Economic Growth. Quarterly Journal of Economics, 106 (2), pp. 445-502.

Dearden L., Reed H. and Van Reenen J. (2006) The Impact of Training on Productivity and Wages: Evidence from British Panel Data. Oxford Bulletin of Economics and Statistics, 68 (4), pp. 397-421.

Durlauf, S., Johnson P. and Temple J. (2005) Growth econometrics, in: P. Aghion and S. Durlauf (eds) Handbook of Economic Growth, (Amsterdam: North-Holland), pp. 555-677. 
European Training Foundation (ETF) (2008), Impact Assessment Studies and Their Implications for Policy Making, www.etf.eu.int.

Fafchamps M. (2009) Human Capital, Exports and Wages. Economic Development and Cultural Change, 58 (1), pp. 111-142.

Fafchamps M., Zeufack A. and El Hamine S. (2008) Learning to Export: Evidence from Moroccan Manufacturing. Journal of African Economies, 17 (2), pp. 305-55.

Greenaway D., Hine R. and Wright P. (1999) An empirical assessment of the impact of trade on employment in the UK. European Journal of Political Economy, 15 (3), pp. 485-500.

Griliches, Z. and Mairesse J. (1997) Production functions: the search for identification, in: S. Strom (eds), Essays in Honor of Ragnar Frisch, Econometric Society Monograph D Series, (Cambridge: Cambridge University Press), pp. 169-203 .

Johanson, R. K. and Adams A. V. (2004) Skills Development in Sub-Saharan Africa (Washington, DC: The World Bank).

Lee, E. and Vivarelli M. (2005) (Eds) Understanding Globalization, Employment and Poverty Reduction (New York: Palgrave Macmillan).

Muller C. and Nordman C. (2004) Wages and Human Capital in Exporting Firms in Morocco. Document de travail 06, DIAL, Paris, France. 
Murray M. P. (2006) Avoiding Invalid Instruments and Coping with Weak Instruments. Journal of Economic Perspectives, 20 (4), pp. 111-132.

Nordman C. and Wolff F. C. (2007) On-the-job learning and earnings: Comparative evidence from Morocco and Senegal. Document de travail 09, DIAL, Paris, France.

Ramachandran V. and Shah M. K. (1999) Minority entrepreneurs and firm performance in sub-Saharan Africa. Journal of Development Studies, 36 (2), pp. 71-87.

Revenga, A., Riboud M. and Tan H. (1994) The Impact of Mexico's Retraining Program on Employment and Wages (PROBECAT). World Bank Economic Review, 8 (2), pp. 247-77.

Rodrik, D. (1995) Getting Interventions Right: How South Korea and Taiwan Grew Rich. Economic Policy, 10 (20), pp. 55-105.

Rosholm, M., Nielsen H. S. and Dabalen A. (2007) Evaluation of training in African enterprises. Journal of Development Economics, 84 (1), pp. 310-329.

Sargan, J. D. (1958) The Estimation of Economic Relationships with Instrumental Variables. Econometrica, 26 (3), pp. 393-415.

Staiger, D. and Stock J. H. (1997) Instrumental Variables Regression with Weak Instruments. Econometrica, 65 (3), pp. 557 - 586. 
Tybout, J., Clerides S. and Lach S. (1998) Is Learning-by-Exporting Important? Microdynamic Evidence from Colombia, Mexico and Morocco. Quarterly Journal of Economics, 113 (3), pp. 903-947.

Van Biesebroeck, J. (2005) Exporting raises productivity in sub-Saharan African manufacturing firms. Journal of International Economics, 67 (2), pp. 373-391

World Bank (2002), Moroccan manufacturing sector at the turn of the century, http://www-wds.worldbank.org.

Yamauchi F., Poapongsakorn N. and Srianant N. (2009) Technical Change and the Returns and Investments in Firm-level Training: Evidence from Thailand. Journal of Development Studies, 45 (10), pp. 1633-1650.

Zwick, T. (2006) The impact of training intensity on establishment productivity. Industrial Relations, 45 (1), pp. 26-46. 